\title{
K dielu Jána Števčeka
}

\author{
Hana Hrancová (Brno) \\ K dielu Jána Števčeka. Pri príležitosti nedožitého 85. výročia narodenia literárneho vedca, pedagóga, prekla- \\ datelá. Eds. Andrea Bokníková - Peter Darovec. Bratislava: Univerzita Komenského v Bratislave, 2015. 169 \\ s. ISBN 978-80-223-3990-2.
}

V roku 2015 bol vydaný zborník s názvom $K$ dielu Jána Števčeka, ktorý okrem príspevkov významných literárnych vedcov obsahuje rozsiahlu výberovú bibliografiu Jána Števčeka, bibliografiu štúdií, článkov, recenzií o ňom a jeho diele a fotografické prílohy. Zborník vzišiel z konferencie organizovanej Katedrou slovenskej literatúry a literárnej vedy Filozofickej fakulty v Bratislave pri príležitosti nedožitého 85 . výročia narodenia literárneho vedca, pedagóga a prekladatela Jána Števčeka, ktorého s Univerzitou Komenského spájalo viac ako štyridsatročné pôsobenie na tejto katedre, najskôr ako asistent Mikuláša Bakoša a neskôr ako jej vedúci. Konferencia sa konala za účasti vel'mi úzkeho okruhu prítomných, vrátane Števčekových dcér, jeho sestry a najbližšej rodiny. Cielom konferencie nebolo podat' ucelený pohlad na vedeckú činnost' tejto osobnosti, ale vyzdvihnút dopad jeho práce na súčasné vedecké dianie.

Dielo nám ponúka náhlad na niektoré stránky Števčekovej práce a jeho života prostredníctvom 7 štúdií. Príspevok Petra Zajaca sa zameriava na jedno z posledných diel Jána Števčeka Literárno-historické etudy, kde sa venuje jeho úvahám o závojoch pri pokuse charakterizovat Švantnerove romány, pričom vychádza z metafory Májinho závoja, ako ju interpretoval Arthur Schopenhauer. Odhaluje Števčekov štýl myslenia, v ktorom oproti analytickosti Čepanovho uvažovania uprednostňuje poznávaciu syntézu, čím sa hlási práve k Schopenhauerovi, čo v konečnom dôsledku znamená uprednostnenie scelovania pred rozdelovaním. V súvislosti so strhávaním závojov ho Števček v skutočnosti len poodhaluje, nazrie zaň a potom „cúvne“. Podla neho opakované odhalovanie a zahalovanie vyznačuje Števčekov štýl myslenia, na ktorý Zajac poukazuje cez imaginárny Májin závoj a demonštruje to na príklade Švantnerovho románu Život bez konca. Števčekovou špecializáciou na slovenský román sa zaoberá vo svojej štúdii Miloslav Vojtech, ktorý zdôrazňuje chýbajúci dôsledný literárnohistorický kontext v jeho počiatočnom poňatí románu. Snaží sa poukázat na osobitosti a originalitu Števčekovho pokusu o rekonštrukciu dejín slovenského románu a vývin tohto žánru v slovenskej literárnej histórii. Peter Darovec rozoberá jeho postoj k racionalizmu v literatúre, ba dokonca priamo, ako autor hovorí, boj s ním. V texte môžeme vidiet zameranie sa na Števčekovu polemiku s dielom Jonáša Záborského v Dejinách slovenského románu a v Skiciach. Na príklade diel Faustiáda, Dva dni $v$ Chujave a Panslavistický farár demonštruje jeho názor, že racionalizmus nemôže predstavovat základ, na ktorom je možné vybudovat plnohodnotné dielo, a ani v ňom nevidí spôsob, ktorým sa dá dielo plnohodnotne prečítat (Darovec, s. 31). Samotný Števček použil vo svojej tvorbe tieto diela za názorný príklad umeleckej nedostatočnosti racionalizmu ako základu tvorby literárneho textu. Darovec pri svojom rozbore však poukazuje na to, že Števček v rozsiahlej interpretácii Faustiády v Dejinách slovenského románu venuje svoju pozornost' racionalizmu len velmi okrajovo, pričom toto dielo vo svojom základe nepochybne racionalistické je.

O polymúzickost' Jána Števčeka sa zaujíma Andrea Bokníková a vybrala si šest’ okruhov v jeho uchopení poézie, ktoré podla nej priamo súvisia s polymúzickostou: evokovaný svet, báseň ako klenba, apollinairovský princíp, žánrový obrázok, plenér, zátišie, miniatúra a napokon monumentalizácia bud' postavy, alebo detailu. Autorka považuje Števčeka za vel'mi dobrého rétora a znalca 
literatúry, vnímavého voči výtvarnému umeniu a iným možnostiam prezentácie, než sú slová. Tamara Janecová poukazuje na spojitost̉ literárnovedného diela Jána Števčeka s ruskou literatúrou. Nadväzuje na Michaila Bachtina využívaním jeho pojmov vo svojich prácach a na V. Šklovského a B. Tomaševského ako predstavitelov ruského formalizmu. Števček nepodliehal len vplyvu predstavitelov ruskej literárnej vedy, ale aj umeleckej literatúry. Autorka poukazuje aj na jeho hladanie vplyvu ruského realizmu u slovenských autorov, napr. u Martina Kukučína.

Vlastnú osobnú skúsenost’ s týmto literárnym vedcom vyjadruje jeho priatel ešte zo študentských čias, Vladimír Petrík, v štúdii Profesor Ján Števček - ako som ho poznal. Poukazuje na Števčekove osobné a spoločensko-politické pohnútky k výberu jeho ústredných tém tvorby. Autor zobrazuje vztah Števčeka k lyrizovanej próze a motiváciu vybrat si za ústrednú postavu svojho knižného debutu práve postavu Františka Švantnera. Písat o ňom pozitívne nebolo v tých časoch (pätdesiate a šestdesiate roky) jednoduché, ked’že lyrizovaná próza bola považovaná za protipól socialistického realizmu, a teda sa vnímala ako úpadková buržoázna tvorba (Petrík, s. 74). Takisto zdôvodňuje jeho štýl písania Dejín slovenského románu a argumentuje $\mathrm{v}$ prospech zasadenia slovenskej literatúry do európskeho kontextu namiesto literárnohistorického vnímania problematiky.

Vedecké štúdie o Števčekovom diele sú doplnené krátkym príspevkom jeho sestry Ety Spiškovej, ktorá dotvára kompletný obraz osobnosti pripomenutím niekolkých príbehov z jeho života. Okrem spomienok na mladost' a životných peripetií, ktoré z neho sformovali významnú a silnú osobnost', zdôrazňuje aj vel'kú spätost s Františkom Švantnerom a jeho prerod postavenia z pozície učitela na žiaka. Tento zborník je dôkazom toho, že profesor Ján Števček patril nepochybne medzi najvýznamnejšie osobnosti slovenskej literárnej vedy a pripomínat si jeho vedeckú činnost̉ je nesmierne dôležité.

\section{Mgr. Hana Hrancová}

Ústav slavistiky

Filozofická fakulta, Masarykova univerzita

Arna Nováka 1, 60200 Brno, Česká republika

450832@mail.muni.cz 